\title{
PEMANFAATAN BIJI LABU KUNING (Cucurbita moschata) UNTUK PEMULIHAN MORFOLOGI DAN MOTILITAS SPERMATOZOA MENCIT (Mus Musculus) YANG TERPAPAR 2-METOKSIETANOL
}

\author{
Alfiah Hayati, Nina Puspita, dan I.B. Rai Pidada \\ Prodi S-1 Biologi, Departemen Biologi, Fakultas Sains dan Teknologi \\ Universitas Airlangga, Surabaya
}

\begin{abstract}
Research has done to investigate the effect of pumpkin seed extract on morphology and motility of the mices after given of 2-ME. Thirty male mices, 56-63 days with 23-27 g weight were used as experimental animals into 5 groups (2 groups is control and 3 groups is treatment), 6 mices each. The first group is $K_{0}$ which given $0.1 \mathrm{~mL}$ aquades by gavage for 40 days each day, and then $K_{1}$ were given $0.05 \mathrm{~mL}$ $2-M E 200 \mathrm{mg} / \mathrm{kg}$ by intraperitoneally everyday within 5 days, and continued on the giving of aquadest. The next groups are treated groups which given 2-ME, in the first 5 days, then continued to the givings of pumpkin seed extract by gavage. Cucurbita moschata seed extract were given in three doses: 0.5; 1.0; and $2.0 \mathrm{~g} / \mathrm{kg} \mathrm{BB} \mathrm{for} 35$ days. Sperm collected from cauda epididymis. Parameter of sperm quality are morphology and motility. The result shown that Cucurbita moschata seed extract doses $0.5-1.0 \mathrm{~g} / \mathrm{kg} B B$ showed no significant effect and then doses $2.0 \mathrm{~g} / \mathrm{kg} B B$ increased recovery process morphology and motility with significant differences $p<0.05$. The conclutions were Cucurbita moschata seed extract increased recovery process morphology and motility of the mices.
\end{abstract}

Key words: Cucurbita moschata seed, Morphology, Sperm motility

\section{PENGANTAR}

Senyawa 2-metoksietanol (2-ME) merupakan hasil metabolit dari dimethoxy ethilphthalate (DMEP), DMEP merupakan salah satu turunan dari phthalic acid ester (PAEs) yang banyak digunakan sebagai bahan pelentur dalam pembuatan plastik. Jika senyawa DMEP masuk ke dalam tubuh maka akan dihidrolisis menjadi 2-ME yang selanjutnya dioksidasi oleh alkohol dehidrogenase menjadi 2-methoxyacetaldehid (MALD), kemudian di dalam hati diubah menjadi senyawa methoxyacetic acid (MAA) oleh aldehid dehidrogenase. Senyawa 2-ME merupakan bahan toksik dan teratogenik. Studi laboratorium menunjukkan bahwa senyawa ini dapat menurunkan kualitas spermatozoa, meningkatkan terjadinya oligospermia sampai azoospermia (Hayati, 2007).

Mengingat pentingnya kualitas spermatozoa yang dimiliki oleh setiap individu untuk dapat menghasilkan keturunan, sehingga perlu adanya perbaikan kualitas spermatozoa salah satunya dengan menggunakan bahan alami yang murah dan mudah didapatkan yaitu biji labu kuning (Cucurbita moschata). Biji labu kuning mengandung unsur mineral seng $(\mathrm{Zn})$ yang sangat penting bagi organ kesehatan reproduksi, termasuk kelenjar prostat (Anonimus, 2011). Di dalam $100 \mathrm{~g}$ biji labu kuning mengandung mineral Zn sebesar 6,5 mg (Widowati et al., 2008). Fungsi dari mineral $\mathrm{Zn}$ adalah pengembangan fungsi reproduksi pria dan pembentukan spermatozoa.

\section{BAHAN DAN CARA KERJA}

Hewan coba yang digunakan adalah mencit (Mus musculus L.) jantan strain BALB C sebanyak 30 ekor dengan berat badan antara 23-27 g dan berumur 56-63 hari. Mencit diperoleh dari Pusat Veterinaria Farma (PUSVETMA), Surabaya.

Bahan-bahan yang diperlukan dalam penelitian ini adalah larutan 2-ME murni produksi WAKO Pure Chemical Industries Ltd. Jepang, aquades, biji labu kuning (Cucurbita moschata) dari pasar Sokosari Tuban Jawa Timur, etanol $70 \%$, kloroform, larutan $\mathrm{NaCl} 0,9 \%$, pewarna Eosin 1\% dan Negrosin 10\%, pakan mencit Par L produksi Comfed.

Mencit sebanyak 30 ekor diaklimatisasi selama 7 hari serta diberi makan dan minum secara ad libitum, kemudian dikelompokkan menjadi 5 kelompok perlakuan yang terdiri atas dua kelompok kontrol (positif dan negatif) dan tiga kelompok perlakuan dengan variasi dosis ekstrak biji labu kuning berturu-turut 0,$5 ; 1,0$; dan $2,0 \mathrm{~g} / \mathrm{kg} \mathrm{BB}$. Setiap kelompok terdiri atas 6 ekor mencit. Pemberian perlakuan secara oral dengan menggunakan disposible syringe $1 \mathrm{~mL}$ yang ujungnya telah diberi kanul dan injeksi melalui intraperitonial dan dilakukan pada pagi hari pukul 09.00-10.00 WIB selama 40 hari.

Macam-macam pemberian perlakuan: 1) pada kelompok kontrol negatif $\left(\mathrm{K}_{0}\right)$ mencit diberi aquades $0,1 \mathrm{~mL} /$ hari selama 40 hari, 2) control positif $\left(\mathrm{K}_{1}\right)$ mencit diinjeksi intraperitonial $0,05 \mathrm{~mL}$ 2-ME $200 \mathrm{mg} / \mathrm{kg} /$ hari selama 
5 hari, kemudian dilanjutkan dengan pemberian aquades $0,1 \mathrm{~mL} /$ hari melalui gavage selama 35 hari, dan 3) kelompok perlakuan $\mathrm{P}_{1}, \mathrm{P}_{2}$, dan $\mathrm{P}_{3}$ masing-masing terdiri atas enam ekor mencit diinjeksi $0,05 \mathrm{~mL}$ 2-ME $200 \mathrm{mg} / \mathrm{kg}$ melalui intraperitonial satu kali sehari selama 5 hari, kemudian dilanjutkan dengan pemberian ekstrak biji labu kuning dengan variasi dosis selama 35 hari.

Pengamatan morfologi spermatozoa mencit dilakukan dengan cara membuat smear suspensi spermatozoa. Satu tetes spermatozoa mencit diteteskan di satu ujung gelas objek, kemudian diberi 1 tetes eosin $1 \%$ dan 1 tetes negrosin $10 \%$. Gelas objek yang lain diletakkan di ujung yang lain dari gelas objek yang pertama dengan membentuk sudut $45^{\circ}$, kemudian digerakkan sampai menyentuh tetesan sperma. Jika sperma telah mengalir rata di tepi dari gelas objek kedua, gelas objek kedua digerakkan kembali kearah semula sehingga terbentuk lapisan tipis hapusan sperma di gelas objek pertama. Hapusan sperma dikeringanginkan pada suhu kamar selama kurang lebih 5 menit. Pengamatan morfologi spermatozoa mencit dilakukan dengan menggunakan mikroskop cahaya dengan perbesaran mulai dari yang kecil yaitu $40 \times$ dilanjutkan dengan perbesaran $100 \times$ dan perbesaran $400 \times$. Pengamatan dilakukan pada 100 spermatozoa (\%) dengan replikasi pengamatan sebanyak 10 kali untuk setiap mencit (Hayati, et al., 2005). Pengamatan morfologi spermatozoa dibedakan atas spermatozoa normal dan abnormal yang dinyatakan dalam persen. Spermatozoa dikatakan normal apabila bagian kepala melengkung seperti kait, leher lurus dan ekor tunggal berujung bebas. Sedangkan morfologi abnormal bila kepala kecil atau terlalu besar, leher patah atau bercabang, ekor bercabang, menggulung dan patah, terdapat sitoplasma droplet pada kepala, leher atau ekor.

Pengamatan motilitas spermatozoa diamati dengan cara suspensi spermatozoa diambil satu tetes dengan menggunakan pipet tetes kemudian diteteskan ke dalam gelas objek cekung dan ditutup dengan gelas penutup. Pengamatan motilitas spermatozoa dilakukan dengan menggunakan mikroskop cahaya dengan perbesaran $100 \times$ yang telah dipasang mikrometer pada lensa okulernya. Motilitas spermatozoa dihitung setiap 10 detik pada 100 spermatozoa untuk tiap ekor mencit (Hayati, et al., 2005).

Data yang diperoleh diuji dengan ANOVA satu arah dan dilanjutkan dengan uji beda nyata terkecil (BNT) untuk mengetahui bermakna atau tidaknya perbedaan antar pasangan perlakuan (Steel dan Torrie, 1991).

\section{HASIL}

Hasil pengamatan dan penghitungan terhadap morfologi spermatozoa mencit kelompok kontrol (negatif dan positif) dan kelompok perlakuan (variasi dosis ekstrak etanol biji labu kuning 0,$5 ; 1,0 ;$ dan $2,0 \mathrm{~g} / \mathrm{kg} \mathrm{BB}$ ) dapat dilihat pada Gambar 1.

\section{PEMBAHASAN}

Hasil pengamatan menunjukkan bahwa kelainan morfologi spermatozoa terjadi di semua bagian spermatozoa, yaitu bagian kepala, leher, dan ekor. Bentuk kepala yang tidak beraturan (amorfus), kepala kecil (microcephali), ekor patah, bengkok, melingkar atau bercabang dan terdapat citoplasmic droplet. Banyaknya spermatozoa yang mempunyai kelainan morfologi tertinggi tampak pada kelompok kontrol positif (K1), namun setelah pemberian ekstrak kelainan morfologi tersebut berangsur menurun. Pada pemberian dosis ekstrak 2,0 g/kgBB, jumlah spermatozoa yang mempunyai kelainan morfologi sangat sedikit. Persentase morfologi saat ini hampir sama dengan kelompok kontrol negatif (K0).

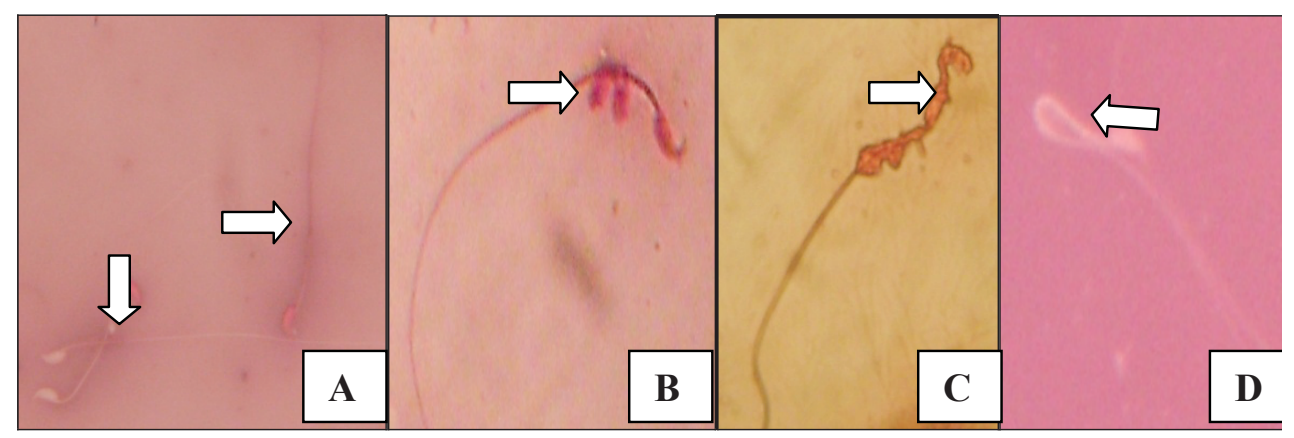

Gambar 1. Morfologi spermatozoa mencit. A. Spermatozoa normal., B-C. Spermatozoa dengan kelainan terdapat citoplasmic droplet., D. Spermatozoa dengan kelainan pada ekor (Perbesaran 400×). 


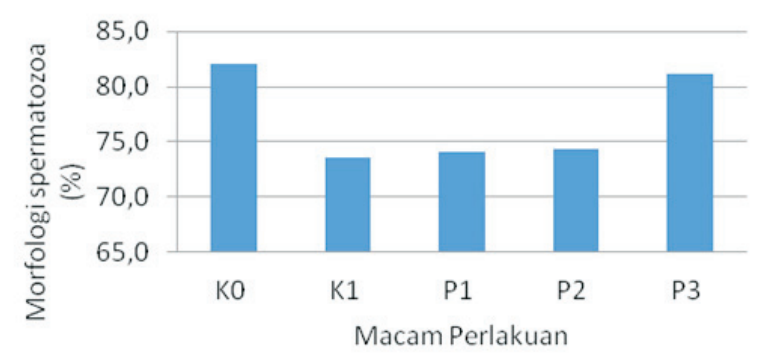

Gambar 2. Diagram batang morfologi spermatozoa mencit (\%) kelompok kontrol $\left(\mathrm{K}_{0}\right.$ dan $\left.\mathrm{K}_{1}\right)$ dan kelompok perlakuan $\left(\mathrm{P}_{1}, \mathrm{P}_{2}\right.$, dan $\mathrm{P}_{3}$ )

Morfologi spermatozoa mengalami kenaikan setelah pemberian ekstrak etanol biji labu kuning. Dari hasil analisis statistik menunjukkan bahwa, kelompok perlakuan mengalami kenaikan morfologi spermatozoa yang signifikan $(\mathrm{p}<0,05)$. Widowati et al. (2008) menyebutkan bahwa, pemberian mineral $\mathrm{Zn}$ menyebabkan meningkatnya sel spermatogenik karena terjadi peningkatan testosteron. Testosteron dari tubulus seminiferus diikat oleh ABP dan ditransportasikan oleh cairan tubulus seminiferus sehingga testosteron mencapai epididimis. Selama di epididimis spermatozoa mengalami proses pendewasaan. Di dalam epididimis testosteron diubah oleh enzim $5 \alpha$ reduktase menjadi DHT yang berfungsi menghilangkan sisa-sisa sitoplasma yang menempel di spermatozoa setelah keluar dari tubulus seminiferus. Meningkatnya DHT menyebabkan mekanisme penghilangan sisa-sisa sitoplasma menjadi lebih efektif, sehingga menimbulkan perbaikan pada morfologi normal spermatozoa.

Hasil pengamatan terhadap kecepatan motilitas spermatozoa antara kelompok kontrol dan kelompok perlakuan (variasi dosis ekstrak 0,5;1,0;2,0 g/kg BB) dapat dilihat pada Gambar 3.

Motilitas spermatozoa meningkat setelah pemberian ekstrak etanol biji labu kuning. Dari hasil analisis statistik menunjukkan bahwa pemberian ekstrak etanol biji labu kuning meningkatkan motilitas spermatozoa secara signifikan $(\mathrm{p}<0,05)$.

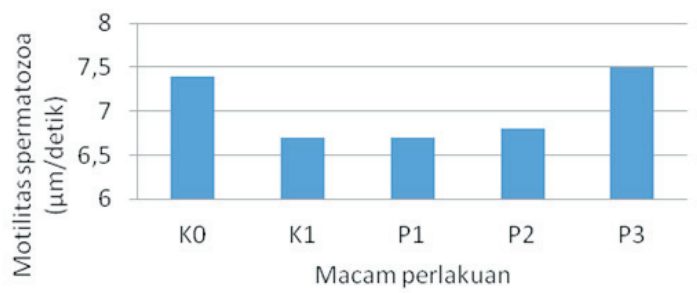

Gambar 3. Diagram batang motilitas spermatozoa mencit $(\mu \mathrm{m} /$ detik) kelompok kontrol $\left(\mathrm{K}_{0}\right.$ dan $\left.\mathrm{K}_{1}\right)$ dan kelompok perlakuan $\left(\mathrm{P}_{1}\right.$, $\mathrm{P}_{2}$, dan $\mathrm{P}_{3}$ )
Kecepatan motilitas spermatozoa yang rendah dipengaruhi oleh banyak faktor, di antaranya adalah adanya kelainan morfologi. Terdapat korelasi positif antara penurunan persentase morfologi spermatozoa dengan kecepatan motilitanya (Hayati, 2007). Morfologi yang tidak normal dapat disebabkan karena terjadinya gangguan pada mekanisme spermiogenesis di testis. Hal ini mengakibatkan banyak spermatozoa yang dilepaskan dari epitel germinal mengandung citoplasmic droplet. Selain itu terjadinya gangguan pada proses pembersihan citoplasmic droplet di epididimis juga meningkatkan persentase morfologi yang tidak normal. Adanya citoplasmic droplet ini menyebabkan penurunan motilitas spermatozoa (Agarwal, 2002).

Senyawa 2-ME menurunkan kualitas spermatozoa karena adanya senyawa MAA hasil metabolit 2-ME yang menyebabkan stres oksidatif yang meningkatkan kadar Reactive Oxygen Species (ROS). Kadar ROS yang tinggi dapat mengoksidasi lipid, protein dan DNA. Oksidasi lipid pada membran spermatozoa menghasilkan senyawa malondialdehyde (MDA), yang bersifat toksik pada sel, sehingga menyebabkan kerusakan membran spermatozoa (Hayati, 2007). Kerusakan membran spermatozoa menyebabkan struktur vital dan fungsinya berubah.

Selain itu 2-ME juga berpengaruh terhadap kecepatan motilitas spermatozoa. Berdasarkan hasil penelitian kecepatan motilitas spermatozoa kelompok kontrol negatif $\left(\mathrm{K}_{0}\right)$ lebih tinggi dibandingkan dengan kelompok kontrol positif $\left(\mathrm{K}_{1}\right)$. Penurunan kecepatan motilitas spermatozoa disebabkan oleh meningkatnya permeabilitas membran spermatozoa oleh MAA yang menyebabkan kerusakan pada mitokondria karena penumpukan ion $\mathrm{Ca}^{2+}$. Kelebihan ion $\mathrm{Ca}^{2+}$ akan menghambat fosforilasi oksidatif sehingga cadangan energi (ATP) menjadi berkurang karena dipakai memompa kelebihan $\mathrm{Ca}^{2+}$ keluar. Cadangan energi yang berkurang menyebabkan menurunnya kecepatan motilitas pada spermatozoa (Rumanta et al., 2001).

Widowati et al. (2008) menyebutkan bahwa, pemberian mineral Zn menyebabkan meningkatnya sel spermatogenik karena terjadi peningkatan testosteron. Mineral Zn ini juga terkandung dalam ekstrak biji labu kuning, sehingga pemberian ekstrak dapat meningkatkan testosteron. Testosteron di epididimis diubah menjadi DHT oleh enzim $5 \alpha$ reduktase. Hormon DHT ini berfungsi menghilangkan citoplasmic droplet pada spermatozoa sehingga spermatozoa yang dilepaskan dari epididimis memiliki motilitas tinggi. Jika testosteron dan DHT di epididimis mengalami peningkatan, maka proses penghilangan citoplasmic droplet menjadi lebih baik dan spermatozoa yang keluar dari epididimis motilitasnya juga akan meningkat. 
Kesimpulan dari penelitian ini adalah pemberian ekstrak etanol biji labu kuning dosis 2,0 g/kg BB meningkatkan proses pemulihan morfologi dan motilitas spermatozoa mencit setealh terpapar senyawa 2-metoksietanol.

\section{SARAN}

Pemberian ekstrak etanol biji labu kuning dengan dosis $2,0 \mathrm{~g} / \mathrm{kg}$ BB dapat digunakan untuk membantu proses pemulihan kualitas spermatozoa dari kualitas yang rendah menjadi keadaan normal.

\section{KEPUSTAKAAN}

Agarwal, A. 2002. Significance of Oxidative Stress and Sperm Chromatin Damage in Male Infertility, chapter 13, www. clevelandclinic. Org.reproductionresearchcenter/docs/ agrach014

Anonimus. 2011. Khasiat Buah Labu Kuning, http://khasiatbuah. com, 30 Oktober 2011.
Hayati, A., Rahmaninta, A.D., dan Pidada, R. 2005. Spermatozoa Motility and Morphological Recovery Process in Mice after the Induction of 2-Methoxyetanol, Journal of Folia Medica Indonesiana, 41(2): 90-95.

Hayati, A. 2007. Kajian kualitas dan protein membran spermatozoa tikus (Rattus norvegicus) akibat pemaparan 2-metoksietanol, Disertasi, UGM, Yogyakarta.

Rumanta, M., Tien, W.S., dan Sudarwati, S. 2001. Pengaruh Asam Metoksiasetat terhadap Organ Reproduksi Mencit (Mus musculus) Swiss Webster Jantan. Jurnal Kedokteran dan Farmasi 33: 61-7.

Sharlip, I.D., Jarow, J.P., Belker, A.M., Lipshultz, L.I., Sigman, M., dan Thomas, A.J. 2002. Best Practice Policies for Male Infertility. Fertil Steril 77(5): 829-843.

Steel, R.G.D., dan J. Torrie. 1991, Prinsip dan Prosedur Statistika Suatu Pendekatan Biometric, Alih Bahasa Bambang Sumantri, PT Gramedia Pustaka Utama, Jakarta. 51-62.

Widowati, W., Sastiono, A., dan Rumampuk, R.J. 2008. Efek Toksik Logam. Penerbit Andi Yogyakarta, Yogyakarta. 309-325. 